\title{
KELAYAKAN USAHA TERNAK DOMBA DENGAN INTRODUKSI PAKAN SILASE DAUN SINGKONG (Kasus di Desa Petir, Kecamatan Dramaga Kabupaten Bogor)
}

\author{
Sabila Mumtaz Khandari'), dan Siti Jahroh') \\ ${ }^{1,2)}$ Departemen Agribisnis, Fakultas Ekonomi dan Manajemen, Institut Pertanian Bogor \\ ${ }^{1)}$ sabilamkhandari@gmail.com
}

\begin{abstract}
The majority of sheep farmers in Indonesia are small-scale ones who use grass which depends on weather as the feed. Petir Village is one of the villages in Bogor Sub-district where the sheep farmers raise their sheep traditionaly. Cassava leaf silage can be an alternative of good quality feed. Introduction of cassava leaf silage can affect the feasibility of livestock business. This study aimed to analyze the feasibility of sheep farming in terms of financial and nonfinancial aspects of introducing cassava leaf silage. Feasibility of non-financial aspects were analyzed using the legal, markets and marketing, management, technical, social, and environmental impact aspects. Whereas feasibility of financial aspects were analyzed using the feasibility criterias Net Present Value (NPV), Internal Rate of Return (IRR), Net Benefit-Cost Ratio (Net B/C), Gross Benefit-Cost Ratio (Gross B/C), and Payback Period. By introducing cassava leaf silage, the results of market and marketing, social, and environmental aspects showed that the business was feasible. Meanwhile, the result of financial analysis on the condition of introducing cassava leaf silage feed was not feasible for any business scale. Cassava leaf silage was not feasible when done individually so the formation of farmer groups can be a solution. In addition, farmers need information and training related to the implementation of cassava leaf silage to sheep.
\end{abstract}

Keyword(s): feasibility, financial aspects, non financial aspects, introduction of cassava leaves silage

\begin{abstract}
ABSTRAK
Mayoritas peternak domba di Indonesia berskala kecil di mana mereka menggunakan rumput sebagai pakan yang tergantung pada cuaca. Desa Petir merupakan salah satu desa di Kecamatan Bogor di mana terdapat peternak domba yang tradisional. Silase daun singkong dapat menjadi pakan alternatif dengan kualitas yang baik. Introduksi pakan silase daun singkong dapat mempengaruhi kelayakan usaha peternakan. Penelitian ini bertujuan untuk menganalisis kelayakan peternakan domba dalam hal aspek finansial dan nonfinansial introduksi silase daun singkong. Kelayakan aspek nonfinansial dianalisis melalui aspek hukum, aspek pasar dan pemasaran, aspek manajemen, aspek teknis, aspek sosial, dan aspek dampak lingkungan. Selanjutnya, kelayakan aspek finansial dianalisis melalui kriteria kelayakan Net Present Value (NPV), Internal Rate of Return (IRR), Net Benefit-Cost Ratio (Net B/C), Gross Benefit-Cost Ratio (Gross B/C), dan Payback Period. Dalam kondisi dengan adanya introduksi silase daun singkong, hasil aspek pasar dan pemasaran, aspek sosial, dan aspek lingkungan menunjukkan layak. Sementara itu, hasil analisis finansial pada kondisi dengan introduksi daun singkong pakan silase tidak layak pada setiap skala usaha. Secara individual introduksi silase daun singkong tidak layak dijalankan, pembentukan kelompok dapat menjadi salah satu solusi. Selain itu, peternak memerlukan informasi serta pelatihan terkait penerapan silase daun singkong pada domba.
\end{abstract}

Kata Kunci: aspek finansial, aspek non finansial, introduksi silase daun singkong, kelayakan 


\section{PENDAHULUAN}

Desa Petir merupakan salah satu desa di Kabupaten Bogor yang menerapkan peternakan domba rakyat. Hasil observasi menunjukkan bahwa usaha ternak yang dijalani masih tradisional dan sederhana dengan skala usaha sekitar 5 - 20 ekor. Mayoritas peternak di Desa Petir menggunakan rumput sebagai pakan ternak yang ketersediaannya sangat dipengaruhi oleh kondisi cuaca. Adanya keterbatasan pakan pada musim kemarau dapat diantisipasi dengan mengembangkan inovasi pakan, salah satunya pakan silase daun singkong.

Penggunaan silase sebagai pakan ternak pun memiliki keunggulan bagi pertumbuhan dan kesehatan ternak (Sapienza dan Bolsen 1993, Mc Donald 1991, Noveanto 2013). Hasil penelitian Noveanto (2013) pada Lampiran 1 diharapkan dapat diterapkan di kalangan petani meskipun dengan cara tradisional. Abdullah (2014) menyatakan bahwa biaya pakan selama 10 tahun terakhir meningkat dari $60 \%$ hingga $80 \%$ dari biaya produksi. Peningkatan tersebut karena adanya ketergantungan terhadap bahan konsentrat yang diimpor. Hasil penelitian Noveanto (2013) menunjukkan bahwa skanario T3 (60\% rumput gajah $+40 \%$ silase daun singkong) merupakan skenario yang paling sesuai untuk diterapkan di Desa Petir dibandingkan dengan skenario lainnya yang menggunakan konsentrat.

Penggunaan silase daun singkong diharapkan dapat meningkatkan produksi ternak di Desa Petir. Namun, adanya introduksi pakan silase daun singkong tentunya membutuhkan peralatanperalatan yang sebelumnya tidak digunakan oleh peternak domba di Desa Petir. Oleh karena itu, perlu dilakukan analisis kelayakan usaha ternak domba di Desa Petir baik pada kondisi aktual maupun kondisi dengan adanya introduksi pakan silase daun singkong.

Tujuan penelitian ini adalah menganalisis kelayakan usaha ternak domba di Desa Petir pada kondisi adanya introduksi pakan silase daun singkong dilihat dari aspek non finansial dan finasial.

\section{METODE PENELITIAN}

Penelitian ini dilakukan dengan observasi dan wawancara secara langsung kepada beberapa peternak domba di Desa Petir dalam berbagai skala usaha yang ditentukan secara purposive yaitu responden pada skala I adalah peternak dengan jumlah ternak domba kurang dari 5 ekor, responden pada skala II adalah peternak dengan jumlah ternak 5 - 10 ekor sedangkan responden pada skala III adalah peternak dengan jumlah ternak lebih dari 10 ekor. Penentuan jumlah ternak dilakukan untuk mendapatkan sebaran biaya di setiap skala.

Analisis data diolah secara kualitatif dan kuantitatif. Data kualitatif dianalisis untuk mengkaji aspek hukum, aspek pasar dan pemasaran, aspek manajemen, aspek teknis, aspek sosial, dan aspek dampak lingkungan yang diperoleh apabila introduksi silase daun singkong akan diterapkan di Desa Petir. Sedangkan analisis kuantitatif dilakukan dengan 
menganalisis kelayakan aspek finansial usaha ternak domba di Desa Petir dengan adanya introduksi pakan silase daun singkong melalui kriteria kelayakan menurut Nurmalina et al. (2009) dan Gittinger (1986) sebagai berikut

$$
\begin{aligned}
& \mathrm{NPV}=\sum_{\mathrm{t}=1}^{\mathrm{n}} \frac{\mathrm{Bt}-\mathrm{Ct}}{(1+\mathrm{i})^{\mathrm{t}}} \\
& \mathrm{IRR}=\mathrm{i}_{1}+\frac{\mathrm{NPV}_{1}}{\mathrm{NPV}_{1}-\mathrm{NPV}_{2}} \mathrm{x}\left(\mathrm{i}_{2}-\mathrm{i}_{1}\right) \\
& \text { Net } \mathrm{B} / \mathrm{C}=\frac{\sum_{t=1}^{n} \frac{B t-C t}{(1+i)^{t}}}{\sum_{t=1}^{n} \frac{B t-C t}{(1+i)^{t}}} ; \frac{B t-C t>0}{B t-C t<0} \\
& \text { Gross } \mathrm{B} / \mathrm{C}=\frac{\sum_{\mathrm{t}=1}^{\mathrm{n}} \frac{\mathrm{Bt}}{(1+\mathrm{i})^{\mathrm{t}}}}{\sum_{\mathrm{t}=1}^{\mathrm{n}} \frac{\mathrm{Ct}}{(1+\mathrm{i})^{\mathrm{t}}}} \\
& \text { Payback Period }=\frac{I}{A_{b}}
\end{aligned}
$$

Keterangan:

$\mathrm{NPV}=$ Net Present Value $(\mathrm{Rp})$

$\mathrm{IRR}=$ Internal Rate of Return $(\mathrm{Rp})$

$\mathrm{B}_{\mathrm{t}} \quad=$ Penerimaan di tahun ke-t $(\mathrm{Rp})$

$\mathrm{C}_{\mathrm{t}} \quad=$ Biaya di tahun ke-t $(\mathrm{Rp})$

$\mathrm{i} \quad=$ Tingkat diskonto $(\%)$

I = Jumlah modal investasi (Rp)

$\mathrm{A}_{\mathrm{b}} \quad=$ Manfaat bersih rata-rata/tahun yang diolah dengan Microsoft Office Excel 2007. Perhitungan biaya dan manfaat disusun dalam bentuk cash flow.

\section{Asumsi Dasar dalam Analisis}

1. Analisis finansial diperhitungkan secara non tunai. Sejumlah komponen yang pada kondisi aktual tidak diperhitungkan biayanya, dalam penelitian ini diperhitungkan. Misalnya, rumput hijauan dan tenaga kerja.

2. Modal yang digunakan para peternak domba di Desa Petir merupakan modal sendiri dan pinjam ke kerabat dengan sistem bagi hasil sebesar 50 persen dari selisih harga jual domba hasil penggemukan dengan harga bakalan domba.
3. Tingkat suku bunga yang digunakan dalam penelitian ini adalah tingkat suku bunga kredit BRI 12\% pada bulan februari 2014.

4. Biaya tenaga kerja dalam keluarga diperhitungkan dan diasumsikan sama dengan rata-rata upah biaya tenaga kerja luar di wilayah tersebut pada bulan Februari 2014, yaitu sebesar Rp 45.000,00 per hari selama 5 jam (dari pukul 07.00 hingga 12.00, sehingga diperhitungkan biaya tenaga kerja per jamnya sebesar Rp 9.000,00

5. Berdasarkan Prawoto et al. 2004 dalam Kusumaningrum 2013 dan Wahyono 2013 rata-rata penambahan bobot harian domba pada umumnya adalah 30 gr/ekor/hari. Noveanto 2013 menunjukkan dengan menggunakan silase daun singkong, penambahan bobot harian domba sebesar 48.57 gr/ekor/hari. Maka masa penggemukan domba dengan adanya introduksi pakan silase daun singkong dapat dipersingkat menjadi sekitar 4 bulan.

6. Jumlah domba pada setiap skala yang digemukkan pada setiap masa penggemukan diasumsikan sama dan penjualan dilakukan setelah satu periode selesai dan domba habis terjual dengan sistem penjualan tongkrong atau dengan menerka bobot domba.

7. Umur ekonomis usaha penelitian ini 3 tahun berdasarkan umur kandang.

8. Harga input dan output yang digunakan dianggap konstan, yaitu saat waktu penelitian dilakukan pada bulan Februari 2014.

9. Penyusutan dihitung dengan metode garis lurus yaitu: 
Penyusutan $=\underline{\text { Nilai beli }- \text { nilai sisa }}$

Umur ekonomis

10. Pajak pendapatan yang digunakan berdasarkan Undang-Undang Republik Indonesia No. 36 Tahun 2008, pasal 17 ayat 2a yaitu dengan tarif pajak sebesar 25\% dari penghasilan usaha.

11. Harga domba bakalan dengan ukuran yang relatif sama sebesar Rp 700.000,00 pada bulan Februari 2014.

12. Penerimaan terdiri atas penjualan domba di penampung (tengkulak) dengan bobot domba di akhir masa penggemukan dihargai sebesar Rp 1.200.000,00 per ekor dan penjualan atas pupuk dengan harga $\mathrm{Rp}$ $5.000,00$ per karung.

\section{ANALISIS ASPEK-ASPEK NON FINANSIAL INTRODUKSI PAKAN SILASE DAUN SINGKONG Aspek Hukum}

Berdasarkan Undang-Undang No. 2008 Tahun 2009 Pasal 19 ayat 2, usaha ternak domba di Desa Petir dengan introduksi pakan silase daun singkong harus dibina oleh pemerintah dan pemerintah daerah guna mencukupi dan memenuhi kebutuhan pakan yang baik untuk ternaknya. Selain itu, berdasarkan Undang-Undang No. 2008 Tahun 2009 Pasal 21 kandungan bahan pencemar fisik, kimia, dan biologis pada pakan silase daun singkong perlu diuji sesuai dengan ketetapan Menteri Pertanian. Ternak domba sebagai sumber pangan manusia perlu memperoleh pakan yang baik, sehingga pangan yang dikonsumsi manusia pun baik.
Melihat kondisi yang berlangsung di Desa Petir, maka dilihat dari aspek hukum introduksi pakan silase daun singkong tidak layak dijalankan. Usaha ternak domba di Desa Petir perlu melakukan perizinan usaha pada pemerintah setempat, akan lebih baik usaha ternak domba di Desa Petir juga terbentuk ke dalam kelompok ternak. Sehingga pengadaan pakan, pembinaan, dan pengujian kandungan pakan dapat dilakukan lebih mudah.

\section{Aspek Pasar dan Pemasaran}

Penggunaan pakan silase daun singkong dan rumput gajah yang digunakan berdasarkan skenario T3 pada Lampiran 1 mampu meningkatkan $\mathrm{PBBH}$ sekitar 48,57 gram. Berdasarkan Prawoto et al. (2004) dalam Kusumaningrum (2013) dan Wahyono (2013) rata-rata penambahan bobot harian domba pada umumnya adalah $30 \mathrm{gr} / \mathrm{ekor} / \mathrm{hari}$. Noveanto (2013) menunjukkan dengan menggunakan silase daun singkong, penambahan bobot harian domba sebesar 48.57 gr/ekor/hari. Maka masa penggemukan domba dengan adanya introduksi pakan silase daun singkong dapat dipersingkat menjadi sekitar 4 bulan. Produksi domba diperkirakan per tahunnya dengan masa penggemukan 4 bulan dapat dilihat pada Tabel 1.

Dengan masa penggemukan yang lebih cepat dapat meningkatkan market share peternak domba di Desa Petir, yang mana diasumsikan bahwa kebutuhan domba di tengkulak tidak mengalami perubahan. Dengan kata lain, penerapan pakan silase daun singkong pada usaha 
Tabel 1. Rata-Rata Kebutuhan dan Produksi Diperkirakan dengan Masa Penggemukan 4 Bulan (Ekor)

\begin{tabular}{lcc}
\hline & Kebutuhan & Produksi \\
\hline P1 & 4590 & 1530 \\
P2 & 2550 & 765 \\
P3 & 3380 & 1155 \\
P4 & 3380 & 885 \\
\hline
\end{tabular}

Keterangan: $\mathrm{Pi}=$ Penampung; $\mathrm{i}=1 . .4$

ternak domba di Desa Petir layak untuk dijalankan.

Pada strategi produk (product), domba yang dijual merupakan domba hasil penggemukan hidup. Dengan menggunakan pakan silase daun singkong kualitas dari domba yang diproduksi lebih tinggi dibandingkan dengan menggunakan pakan rumput biasanya. Sapienza dan Bolsen (1993) menyatakan bahwa keunggulan dari silase adalah sebagai promotor pertumbuahan dan penghambat penyakit. Strategi dengan menggunakan pakan silase daun singkong guna meningkatkan kualitas domba adalah tepat.

Penetapan harga (price) domba hasil penggemukan selama 6 (enam) bulan dihargai Rp 1.200.000,00 per ekor, namun untuk beberapa peternak yang mampu menggemukan domba dengan baik hanya membutuhkan waktu 3-4 bulan masa penggemukan dengan harga jual yang sama. Dengan domba yang memiliki keunggulan lebih dapat meningkatkan daya tawar dari peternak domba di Desa Petir. Sedangkan untuk transaksi penjualan pupuk atau kotoran domba dilakukan di kebun tani yang dihargai $\mathrm{Rp}$ 5.000,00 per karung.

Dilihat berdasarkan bauran pemasaran yang diterapkan, introduksi pakan silase daun singkong layak untuk dijalankan.

\section{Aspek Teknis}

Umumnya peternak domba di Desa Petir sudah menggunakan kandang panggung beratap dengan ruang kamar untuk satu ekor ternak. Kandang panggung menciptakan ruang kamar kandang yang lebih bersih, sebab kotoran akan jatuh ke bawah tidak menumpuk di dasar kandang (Chaniago 1993). Selain itu, dengan menggunakan kandang panggung akan memudahkan peternak saat mengambil kotoran yang sudah menumpuk di bawah kandang. Sedangkan ruang kamar berfungsi sebagai pemisah antar ternak, sehingga ternak tidak berebut pakan. Ukuran ruang kamar setiap ekor sekitar $4075 \mathrm{~cm}$ x $100-150 \mathrm{~cm}$, sesuai dengan pernyataan Sutama dan Budiarsana (2009) bahwa kandang penggemukan merupakan kandang individual dengan ukuran yang relatif kecil sekitar $75 \mathrm{~cm} \mathrm{x}$ $100 \mathrm{~cm}$. Hal tersebut dilakukan untuk membatasi ruang gerak ternak, sehingga tingkat kehilangan energi pada ternak menjadi lebih rendah. Dengan kata lain, luasan produksi yang diterapkan peternak domba di Desa Petir layak. 
Letak kandang penggemukan domba yang dilakukan peternak di Desa Petir umumnya berada tidak jauh dari rumah tinggal. Letak kandang berada sekitar 2-7 meter dari rumah tinggal. Jarak kandang tersebut tergantung pada kepemilikan lahan peternak. Sedangkan, Hadi et al. (2006) menyatakan bahwa penempatan kandang ternak harus terpisah dari rumah, minimal berjarak 10-20 meter.

Mengubah input pakan rumput menjadi pakan silase daun singkong dan rumput gajah berakibat pada ketersediaan input di wilayah Desa Petir. Rumput gajah tidak banyak ditanam di Desa Petir, namun dapat diperoleh di wilayah Dramaga. Dalam penelitian Noveanto (2013) rumput gajah yang digunakan tidak dibuat menjadi silase, sehingga peternak harus mencari rumput gajah setiap harinya. Jumlah ternak domba di Desa Petir tidak sedikit, apabila skenario T3 diterapkan oleh semua peternak maka rumput gajah akan semakin sulit diperoleh. Sedangkan, daun singkong dapat diperoleh dari panen singkong, yang mana saat panen singkong daunnya dibiarkan saja di kebun. Karena itu, untuk memperoleh daun singkong peternak perlu bekerjasama dengan para tengkulak singkong di wilayah Dramaga. Hal tersebut akan mengeluarkan biaya komunikasi dan biaya transportasi yang lebih tinggi dibandingkan dengan kondisi aktual. Namun, dengan metode tersebut akan mempermudah peternak untuk memperoleh daun singkong. Selain itu, untuk pembuatan pakan silase daun singkong dibutuhkan molases, yang mana molases tersedia di toko pakan ternak di wilayah Jalan Baru Bogor.
Ketersediaan input-input pendukung seperti obat-obatan dan vitamin sama seperti kondisi aktual. Sedangkan untuk peralatan tambahan dalam proses pembuatan pakan silase daun singkong dapat diperoleh di beberapa wilayah. Pisau, tatakan, trashbag dan plastik tahan panas dapat diperoleh di Pasar Dramaga, dan gentong plastik dapat diperoleh di kawasan Leuwikopo. Secara menyeluruh peralatan tersebut dapat diakses di wilayah Dramaga sehingga masih cukup mudah diakses, namun akan menambah biaya transportasi.

Berdasarkan ketersediaan input usaha ternak domba dengan introduksi pakan silase daun singkong kurang layak dijalankan. Hal tersebut dikarenakan input-input utama untuk pakan itu sendiri tidak tersedia dengan mudah di Desa Petir. Selain itu, jumlah peternak domba di Desa Petir yang tidak sedikit dan jumlah ternak yang beragam membutuhkan jumlah daun singkong dan rumput gajah yang beragam pula. Karena itu, perlu dilakukan penelitian terkait kualitas campuran pakan silase daun singkong dengan rumput sekitar atau kualitas pakan silase berbahan dasar rumput sekitar Desa Petir.

Proses produksi yang dilakukan peternak domba di Desa Petir dengan introduksi pakan silase daun singkong diawali dengan tahap pembuatan pakan silase daun singkong, lalu tahapan lainnya seperti yang dilakukan kegiatan usaha ternak domba di Desa Petir pada kondisi aktual. Namun, untuk menerapkan pakan silase daun singkong setiap 3 minggu perlu membuat pakan silase daun singkong terus menerus hingga akhir 
masa penggemukan. Hal tersebut dikarenakan pakan silase daun singkong melalui proses fermentasi selama 3 minggu.

Proses pembuatan pakan silase daun singkong membutuhkan daun singkong, molases, gentong plastik, plastik tahan panas, karet gelang, pisau, dan tatakan. Daun singkong dipotong-potong dengan ukuran sekitar 2-3 cm, kemudian dilayukan dengan cara diangin-anginkan di atas terpal selama minimal 6 jam. Selanjutnya daun singkong yang telah dilayukan diberi molases sebanyak 5\% dari bobot daun singkong, pemberian molases sambil diaduk secara merata pada daun singkong. Setelah daun singkong dan molases teraduk rata, maka masukkan campuran tersebut ke dalam plastik tahan panas hingga padat dan tidak ada udara (akan lebih mudah jika menggunakan vacum), serta ikat menggunakan karet gelang atau lakban. Kemudian masukkan daun singkong yang sudah dikemas ke dalam gentong agar aman dari gangguan dan tidak terkena cahaya matahari, tutup selama 3 minggu. Pakan silase daun singkong dapat digunakan setelah 3 minggu dan dapat disimpan hingga 1 tahun (jika tidak dibuka) tanpa mengubah kualitas pakan (Noveanto 2013).

Pembuatan pakan silase daun singkong membutuhkan tenaga kerja dan waktu yang banyak. Proses pemotongan daun singkong sangat tergantung dengan kecepatan tangan tenaga kerja, sehingga lama waktu pemotongan dapat berbeda pada masing-masing usaha. Selain itu, proses fermentasi yang dilakukan dapat mengalami kegagalan jika daun singkong yang dicampur dengan molases kurang padat pengemasannya. Kegagalan produksi silase daun singkong tersebut berupa pembusukan. Hal ini dapat mengakibatkan kegagalan ketersediaan pakan silase daun singkong yang akan berpengaruh juga pada kegiatan usaha ternak domba. Untuk itu, dibutuhkan tenaga kerja yang sudah memiliki kemampuan membuat pakan silase.

Layout produksi usaha ternak domba yang diterapkan di Desa Petir kurang layak untuk dijalankan jika introduksi pakan silase daun singkong diterapkan. Penggunaan pakan silase daun singkong yang dibuat sendiri akan membutuhkan ruang tambahan untuk pembuatan dan penyimpanan pakan tersebut, terutama pada usaha ternak domba yang memiliki jumlah ternak cukup banyak. Pembuatan pakan silase daun singkong dengan proses penganginan selama 6 jam dan penyimpanan pakan silase dalam gentong tidak boleh terkena sinar matahari langsung, sedangkan kondisi di Desa Petir umumnya kandang berada di luar tanpa bangunan lagi. Dengan kata lain, introduksi pakan silase daun singkong tidak layak dijalankan dilihat dari layout produksi. Karena itu, dibutuhkan lokasi yang memadai dengan sarana dan prasarana bagi peternak guna melakukan pembuatan pakan silase daun singkong, misalnya pembuatan kelompok ternak atau bergabung dengan kelompok tani seperti telah disebutkan pada aspek hukum sebelumnya.

\section{Aspek Manajemen}

Keberhasilan pembuatan pakan silase daun singkong dipengaruhi kualitas tenaga kerja yang digunakan. Pakan 
silase daun singkong dapat gagal diproduksi jika proses fermentasi yang berlangsung tidak baik. Mayoritas responden belum mengetahui definisi maupun prosedur pembuatan pakan silase daun singkong. Sedangkan, untuk membuat pakan silase daun singkong dibutuhkan pengetahuan mengenai proses pembuatan pakan silase daun singkong yang baik. Dengan kata lain, dilihat dari aspek manajemen introduksi pakan silase daun singkong tidak layak dijalankan peternak domba di Desa Petir jika peternak belum mengetahui proses pembuatan pakan silase yang baik.

Berdasarkan permasalahan di atas, kualitas tenaga kerja atau peternak domba di Desa Petir perlu ditingkatkan. Peningkatan kualitas tenaga kerja dapat dilakukan dengan memberikan pelatihan dan pengetahuan mengenai pembuatan pakan silase. Pemberian pelatihan dan pengetahuan ini dapat disampaikan melalui kelompok.

\section{Aspek Sosial}

Peternakan domba rakyat di Desa Petir dengan introduksi pakan silase daun singkong memberikan dampak yang baik bagi peternak dan masyarakat sekitar. Dampak positif yang diterima para peternak adalah dengan masa penggemukan domba menjadi lebih singkat sehingga jumlah domba yang digemukkan dalam setahun $150 \%$ lebih banyak dalam setahun. Sedangkan dampak positif yang dirasakan masyarakat yaitu dengan adanya introduksi pakan silase daun singkong. tenaga kerja masyarakat sekitar dapat diserap usaha ternak domba untuk membantu proses pembuatan pakan silase daun singkong, jika diperlukan. Dengan kata lain, dilihat dari aspek sosial, usaha ternak domba di Desa Petir dengan introduksi pakan silase daun singkong layak untuk dijalankan.

\section{Aspek Dampak Lingkungan}

Dilihat dari Lampiran 1 bahwa kandungan $\mathrm{N}$ pada feses dan urin dengan menggunakan skenario T3 paling tinggi dibandingkan dengan skenario lainnya. Hal tersebut dikarenakan tingginya kandungan protein pada daun singkong tidak diserap dengan baik oleh tubuh ternak. Dilihat dari nilai konsumsi $\mathrm{N}$, retensi $\mathrm{N}$, efisiensi penggunaan nitrogen (EPN), dan nilai biologi protein (NBP) dari Lampiran 1 bahwa tingginya kandungan protein yang dikonsumsi domba tidak sejalan dengan nilai retensi nitrogen, sehingga nilai dari EPN dan NBP rendah. Hal ini mengindikasikan bahwa nitrogen tersebut banyak terbuang pada feses dan urin (Akbar 2007).

Berdasarkan tingginya kandungan $\mathrm{N}$ pada feses dan urin tersebut, jika pakan silase daun singkong $60 \%$ dan rumput gajah 40\% diterapkan sebagai pakan untuk ternak domba di Desa Petir maka tetap memberi dampak positif baik bagi ternak maupun bagi lingkungan. Manfaat bagi ternak adalah nilai PBBH yang lebih tinggi, sedangkan manfaat bagi lingkungan adalah tingginya kandungan $\mathrm{N}$ pada feses dan urin menunjukkan bahwa limbah kotoran yang dihasilkan mengandung lebih banyak nutrisi. Tingginya kandungan $\mathrm{N}$ tersebut baik dimanfaatkan sebagai pupuk organik bagi pertanian di wilayah sekitar. 
Budaya peternak dalam memandikan domba adalah 3 bulan sekali, dengan masa penggemukan 4 bulan maka diasumsikan peternak hanya memandikan 3 kali dalam setahun. Hal tersebut menunjukkan bahwa introduksi pakan silase daun singkong juga lebih ramah lingkungan. Dengan kata lain, usaha ternak domba di Desa Petir dengan introduksi pakan silase daun singkong layak untuk dijalankan.

\section{ANALISIS ASPEK FINANSIAL INTRODUKSI PAKAN}

\section{Analisis Laba Rugi}

Pada kondisi adanya introduksi pakan silase daun singkong menghasilkan nilai rugi pada setiap skala. Besar rugi yang diterima pada skala I adalah $\mathrm{Rp}$ $(2.418 .379,04)$, pada skala II sebesar Rp
(4.046.249,25), dan pada skala III sebesar Rp (5.113.015,42). Hal tersebut disebabkan terutama oleh tidak tersedianya bahan baku dengan mudah di Desa Petir dan kebutuhan tenaga kerja yang banyak dalam proses pembuatannya.

\section{Analisis Kriteria Kelayakan Finansial Kondisi Introduksi Pakan}

Introduksi pakan silase daun singkong membutuhkan peralatan-peralatan baru yang juga akan meningkatkan besar biaya yang dikeluarkan. Hasil analisis kelayakan investasi pada Tabel 2, kondisi adanya introduksi pakan silase daun singkong menunjukkan bahwa investasi yang dilakukan pada usaha ternak domba di Desa Petir tidak layak untuk dijalankan.

Tabel 2. Hasil Analisis Kelayakan Finansial Introduksi Pakan Silase Daun Singkong

\begin{tabular}{|c|c|c|c|c|}
\hline Skala & Kriteria & Nilai & $\begin{array}{c}\text { Indikator } \\
\text { Kelayakan } \\
\end{array}$ & $\begin{array}{c}\text { Hasil } \\
\text { Kelayakan }\end{array}$ \\
\hline \multirow[t]{5}{*}{$\mathrm{I}$} & NPV & $(15.170 .280,43)$ & $>0$ & Tidak Layak \\
\hline & IRR & - & $<0,12$ & Tidak Layak \\
\hline & Net B/C & 0,00 & $>1$ & Tidak Layak \\
\hline & Gross B/C & 0,63 & $>1$ & Tidak Layak \\
\hline & PP & - & $<6$ & Tidak Layak \\
\hline \multirow[t]{5}{*}{ II } & NPV & $(25.600 .629,41)$ & $>0$ & Tidak Layak \\
\hline & IRR & - & $<0,12$ & Tidak Layak \\
\hline & Net B/C & 0,00 & $>1$ & Tidak Layak \\
\hline & Gross B/C & 0,67 & $>1$ & Tidak Layak \\
\hline & PP & - & $<6$ & Tidak Layak \\
\hline \multirow[t]{5}{*}{ III } & NPV & $(31.740 .124,17)$ & $>0$ & Tidak Layak \\
\hline & IRR & - & $<0,12$ & Tidak Layak \\
\hline & Net B/C & 0,00 & $>1$ & Tidak Layak \\
\hline & Gross B/C & 0,80 & $>1$ & Tidak Layak \\
\hline & PP & - & $<6$ & Tidak Layak \\
\hline
\end{tabular}

Keterangan: ${ }^{a}$ Dalam rupiah; ${ }^{b}$ Dalam persen; ${ }^{c}$ Dalam periode 
Hasil kelayakan berdasarkan indikator yang ada menunjukkan tidak layak. Nilai investasi yang dilakukan tidak sebanding dengan nilai biaya yang dikeluarkan. Oleh sebab itu, sebaiknya investasi pembuatan pakan silase daun singkong secara individu tidak dilakukan.

\section{SIMPULAN DAN SARAN}

\section{Simpulan}

1. Usaha ternak domba dengan adanya introduksi pakan silase daun singkong layak dijalankan berdasarkan aspekaspek non finansial, yaitu aspek pasar dan pemasaran, aspek sosial, dan aspek dampak lingkungan. Sedangkan, dilihat berdasarkan aspek hukum, aspek teknis, dan aspek manajemen usaha ternak domba dengan introduksi pakan silase daun singkong di desa Petir tidak layak dijalankan.

2. Usaha ternak domba dengan adanya introduksi pakan silase daun singkong tidak layak dijalankan pada setiap skala usaha. Dapat dilihat dari nilai kriteria investasi yang belum memenuhi kriteria kelayakan secara finansial.

\section{Saran}

1. Investasi pembuatan pakan secara individu pada masing-masing usaha ternak sangat tidak efektif dan efisien. Untuk itu, perlu dilakukan penelitian mengenai analisis kelayakan usaha kelompok yang melakukan investasi peralatan-peralatan untuk pembuatan pakan silase daun singkong.

2. Perlu dilakukan penelitian lanjutan mengenai pakan silase berbahan dasar rumput atau limbah tani di wilayah penelitian, sehingga perolehan input pakan akan lebih mudah. Penelitian yang dapat dilakukan salah satunya adalah penelitian pengujian kualitas pakan silase dengan menggunakan rumput-rumput sekitar.

3. Peternak domba di Desa Petir perlu mendapatkan informasi, pengetahuan, dan pelatihan mengenai pakan silase daun singkong.

\section{DAFTAR PUSTAKA}

Akbar SA. 2007. The Use of Fermented Palm Bunches Trash in Sheep. J. Indon. Trop. Anim. Agric. 32 (2): $80-85$.

Chaniago TD, penghimpun. 1993. Present managing systems. Di dalam: Tomaszewska MW, Gerdiner S, Djajanegara A, Mastika IM, Wiradarya TR, editor. Small Ruminant Production in the Humid Tropics [bibliografi]. Surakarta (ID): Sebelas Maret University Press.

Hadi B, Hadisaputro S, Setyawan H. 2006. Kandang Ternak dan Lingkungan Kaitannya dengan Kepadatan Vektor Anopheles aconitus di Daerah Endemis Malaria (Studi Kasus di Kabupaten Jepara [jurnal]. Semarang (ID): Universitas Diponegoro.

Kusumaningrum CE, Wahyono T, dan Suharyono. 2013. Pengaruh Penggunaan Pakan Komplit Berbasis Limbah Tanaman Jagung dan Sorgum pada Produktivitas Ternak Domba. Seminar Nasional Teknologi Peternakan dan Veteriner 
Noveanto I. 2013. Kecernaan Nutrien, Retensi Nitrogen, dan Sintesis Protein Mikroba pada Domba yang Mendapat Substitusi Konsentrat dengan Silase Daun Singkong [skripsi]. Bogor (ID): Institut Pertanian Bogor.

Nurmalina R, Sarianti T, Karyadi A. 2009. Studi Kelayakan Bisnis. Bogor (ID): Departemen Agribisnis FEM-IPB.

Sapienza DA, Bolsen KK. 1993. Teknologi Silase. Penerjemah: Martoyoedo RBS. Pioner-Hi-Bred Internstional, Inc. Manhattan: Kansas State University Pr.

Sutama I K, Busiarsana IGM. 2009. Panduan Lengkap Kambing dan Domba. Depok (ID): Swadaya.

Wahyono T, Kusumaningrum CE, Widiawati Y, dan Suharyono. 2013. Penampilan Produksi Kambing Kacang Jantan yang Diberi Pakan Siap Saji (PSS) Berbasis Silase Tanaman Jagung. Seminar Nasional Teknologi Peternakan dan Veteriner. 
Lampiran 1. Retensi Nitrogen dan Performa Domba yang Diberi Silase Daun Singkong

\begin{tabular}{lrrrr}
\hline \multirow{2}{*}{\multicolumn{1}{c}{ Parameter }} & \multicolumn{5}{c}{ Perlakuan } \\
\cline { 2 - 5 } & \multicolumn{1}{c}{ T0 } & \multicolumn{1}{c}{ T1 } & \multicolumn{1}{c}{ T2 } & \multicolumn{1}{c}{ T3 } \\
\hline Konsumsi N (g/kg BB) & $1.1 \pm 0.05$ & $1.57 \pm 0.10$ & $1.74 \pm 0.05$ & $1.86 \pm 0.05$ \\
N feses (g/kg BB) & $0.22 \pm 0.03$ & $0.24 \pm 0.02$ & $0.42 \pm 0.03$ & $0.52 \pm 0.04$ \\
N urin (g/kg BB) & $0.57 \pm 0.02$ & $0.54 \pm 0.04$ & $0.71 \pm 0.15$ & $1.01 \pm 0.16$ \\
Retensi N (g/kg BB) & $0.32 \pm 0.02$ & $0.79 \pm 0.13$ & $0.61 \pm 0.09$ & $0.34 \pm 0.19$ \\
EPN (\%) & $28.84 \pm 1.00$ & $50.05 \pm 5.30$ & $35.09 \pm 6.28$ & $17.89 \pm 9.39$ \\
NBP (\%) & $36.10 \pm 1.50$ & $59.11 \pm 5.35$ & $46.42 \pm 8.94$ & $24.88 \pm 13.25$ \\
BB awal (kg) & $11.46 \pm 1.79$ & $11.53 \pm 1.85$ & $11.41 \pm 0.98$ & $11.50 \pm 1.04$ \\
BB akhir (kg) & $12.06 \pm 2.55$ & $17.02 \pm 3.68$ & $16.71 \pm 1.70$ & $15.45 \pm 1.95$ \\
PBBH (g/ekor) & $14.40 \pm 6.70$ & $60.03 \pm 16.93$ & $59.90 \pm 11.93$ & $48.57 \pm 13.01$ \\
\hline T0= $100 \%$ m
\end{tabular}

$\mathrm{T} 0=100 \%$ rumput gajah; $\mathrm{T} 1=60 \%$ rumput gajah $+40 \%$ konsentrat; $\mathrm{T} 2=60 \%$ rumput gajah $+20 \%$ konsentrat $+20 \%$ silase daun singkong; $\mathrm{T} 3=60 \%$ rumput gajah $+40 \%$ silase daun singkong; $\mathrm{EPN}=$ efisiensi penggunaan protein; $\mathrm{NBP}=$ nilai biologi protein; $\mathrm{BB}=$ bobot badan; $\mathrm{PBBH}=$ pertambahan bobot badan harian; pemberian pakan selama 100 hari. 